\title{
RUNOFF HYDROGRAPHS USING SNYDER AND SCS SYNTHETIC UNIT HYDROGRAPH METHODS: A CASE STUDY OF SELECTED RIVERS IN SOUTH WEST NIGERIA
}

\author{
Adebayo Wahab Salami', Solomon Olakunle Bilewu', \\ Adeoye Biliyamin Ibitoye' ${ }^{2}$, Ayanniyi Mufutau Ayanshola' \\ 1 Department of Water Resources and Environmental Engineering, University of Ilorin, Ilorin, Nigeria, e-mail: \\ bilewuk@yahoo.com; engramayanshola@gmail.com \\ 2 Department of Civil and Environmental Engineering, Kwara State University, Malete, Nigeria, e-mail: \\ bilyamin@yahoo.com
}

Corresponding Author's e-mail: awsalami2009@gmail.com

Received: 2016.10.01

Accepted: 2016.10 .23

Published: 2017.01.01

\begin{abstract}
This paper presents the development of runoff hydrographs for selected rivers in the Ogun-Osun river catchment, south west, Nigeria using Snyder and Soil Conservation Service (SCS) methods of synthetic unit hydrograph to determine the ordinates. The Soil Conservation Service (SCS) curve Number method was used to estimate the excess rainfall from storm of different return periods. The peak runoff hydrographs were determined by convoluting the unit hydrographs ordinates with the excess rainfall and the value of peak flows obtained by both Snyder and SCS methods observed to vary from one river watershed to the other. The peak runoff hydrograph flows obtained based on the unit hydrograph ordinate determined with Snyder method for 20-yr, 50yr, 100-yr, 200-yr and 500-yr, return period varied from $112.63 \mathrm{~m}^{3} / \mathrm{s}$ and 13364.30 $\mathrm{m}^{3} / \mathrm{s}$, while those based on the SCS method varied from $304.43 \mathrm{~m}^{3} / \mathrm{s}$ and $6466.84 \mathrm{~m}^{3} / \mathrm{s}$ for the eight watersheds. However, the percentage difference shows that for values of peak flows obtained with Snyder and SCS methods varies from $13.14 \%$ to $63.30 \%$. However, SCS method is recommended to estimate the ordinate required for the development of peak runoff hydrograph in the river watersheds because it utilized additional morphometric parameters such as watershed slope and the curve number $(\mathrm{CN})$ which is a function of the properties of the soil and vegetation cover of the watershed.
\end{abstract}

Keywords: unit hydrograph, runoff hydrograph, storm duration, watershed, return periods

\section{INTRODUCTION}

Basic stream flow and rainfall data are not adequately available for planning and designing water management facilities and other hydraulic structures in ungauged watershed. This situation is common in Nigeria due to lack of gauging stations along most of the rivers and streams. However, techniques have been evolved that allow generation of synthetic unit hydrographs. This includes Snyder, Soil Conservation Service (SCS), Gray and Clark's Instantaneous Unit Hydrograph methods. The peak discharges of stream flow from rainfall can be obtained from the de- sign runoff hydrographs developed from unit hydrographs ordinates determined from established methods. Warren et al. [1972] described hydrograph as a continuous graph showing the properties of stream flow with respect to time, normally obtained by means of a continuous strip recorder that indicates stages versus time and is then transformed to a discharge hydrograph by application of a rating curve. Wilson [1990] observed that with an adjustment and well measured rating curve, the daily gauge readings may be converted directly to runoff volume. He also emphasized that catchment properties influence runoff and each may be present to a large or small 
degree. The catchment properties include area, slope, orientation, shape, altitude and also stream pattern in the basin. The unit hydrograph (UH) of a drainage basin, according to Varshney [1986] is defined as the hydrograph of direct runoff resulting from one unit of effective rainfall of a specified duration, generated uniformly over the basin area at a uniform rate. Arora [2004] defined 1-hr unit hydrograph as the hydrograph which gives $1 \mathrm{~cm}$ depth of direct runoff when a storm of $1-\mathrm{hr}$ duration occurs uniformly over the catchment.

A vast amount of literature exists treating the various unit hydrograph methods and their development. Jones [2006] reported that Sherman in 1932 was first to explain the procedure for development of the unit hydrograph and recommended that the unit hydrograph method be used for watersheds of 2000 square miles $\left(5000 \mathrm{~km}^{2}\right)$ or less. Chow et al. [1988] discussed the derivation of unit hydrograph and its linear systems theory. Furthermore, Viessman et al [1989], Wanielista [1990] and Arora [2004] presented the history and procedures for several unit hydrograph methods. Ramirez [2000] reported that the synthetic unit hydrograph of Snyder in 1938 was based on the study of 20 watersheds located in the Appalachian Highlands and varying in size from 10 to 10000 square miles (25 to $25000 \mathrm{~km}^{2}$ ). Ramirez [2000] reported that the dimensionless unit hydrograph was developed by the Soil Conservation Service and obtained from the UH's for a great number of watersheds of different sizes and for many different locations. It was also stated by Ramirez [2000] that the SCS dimensionless hydrograph is a synthetic UH in which the discharge is expressed as a ratio of discharge, $Q$, to peak discharge, $Q_{p}$ and the time by the ratio of time, $t$, to time to peak of the UH, $t_{p}$. Wilson [1990] also reported that in 1938, McCarthy proposed a method of hydrograph synthesis but in that same year Snyder proposed a better known method by analyzing a larger number of basins in the Appalachian mountain region of the United States. Ogunlela and Kasali [2002] applied four methods of unit hydrographs generation to develop a unit hydrograph for an ungaged watershed. The outcome of the study revealed that both Snyder and SCS methods were not significantly different from each other. Salami [2009] applied three unit hydrograph methods for runoff hydrograph development of lower Niger River basin at downstream of the Jebba Dam. The methods considered were Snyder, SCS and Gray methods. The statistical analysis, conducted at the $5 \%$ level of significance, indicated significant differences in the methods except for Snyder and SCS methods which have relatively close values. In this study Snyder and SCS methods were used to determine the ordinate of unit hydrographs and was subsequently used to generate peak runoff hydrographs of rainfall depth of various return intervals through convolution for selected rivers in south west, Nigeria. The outcome of the study will make the selection of peak runoff flows of the desire return period for design of hydraulic structures in the region possible.

\section{MATERIALS AND METHODS}

\section{Study Area}

The river catchments under consideration are Fawfaw, Oba, Awon, Opeki, Ogunpa, Osun, Otin and Ogun located in the Ogun - Osun River basin, South West Nigeria as presented in Figure 1.

\section{Development of Unit Hydrograph}

The methods of unit hydrographs used to determine the peak runoff ordinates are; Snyder's and Soil Conservation Service (SCS) methods.

\section{Snyder's method}

In adopting Snyder's method, the following parameters were determined: the peak discharge, lag time and the time to peak, rainfall duration, the peak discharge per unit of watershed area, $q_{p}$, the basin lag $t^{\prime}$, the base time, $t_{b}$, and the widths, $w$ (in time units) of the unit hydrograph at 50 and 75 percent of the peak discharge. The parameters were estimated in accordance to Ramirez [2000] and Arora [2004] using equations (1) to (8).

Lag time, $t_{l}$

$$
t_{l}=C_{t}\left(L^{*} L_{c}\right)^{0.3}
$$

Where $C_{t}$ is a coefficient representing variations of watershed slope and storage. Values of $C_{t}$ range from 1.0 to 2.2 [Arora, 2004]. An average value of 1.60 is assumed for this catchment. Equation (1) gives the lag time for the watershed.

Unit-hydrograph duration, $t_{r}$ (storm duration)

$$
t_{r}=\frac{t_{l}}{5.5}
$$

From equation (2) the duration of the storm was obtained. However, if other storm durations are intended to be generated for the watershed, 


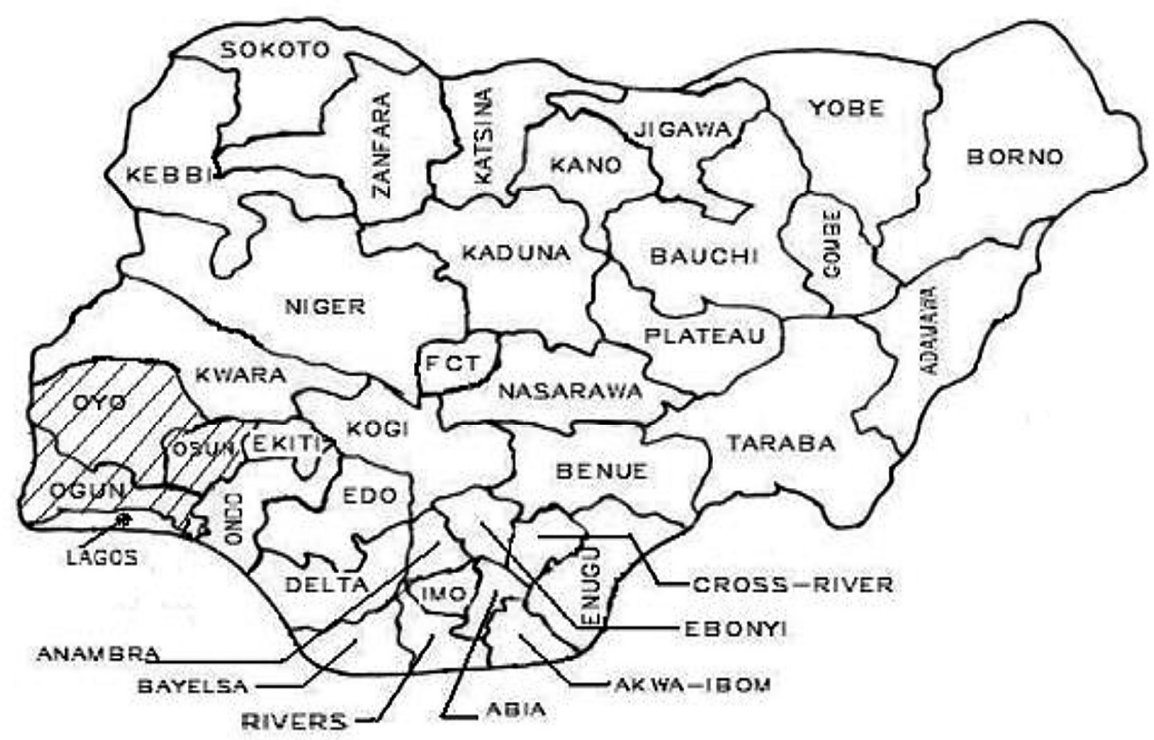

Figure 1. Map of Nigeria showing location of the selected rivers

the new unit hydrograph storm duration $\left(\mathrm{t}_{\mathrm{r}}\right)$, the corresponding basin lag time $\left(\left(\mathrm{t}^{\prime}\right)\right.$ can be obtained from equation (3).

$$
t_{l}^{\prime}=t_{l}+\left(\frac{t_{r}^{\prime}-t_{r}}{4}\right)
$$

The peak discharge $\left(Q_{p}^{\prime}\right)$ was obtained from equation:

$$
Q_{p}^{\prime}=\frac{2.78 * C_{p}^{*} A}{t_{l}^{\prime}}
$$

Where $C_{p}$ is the coefficient accounting for flood wave and storage conditions. Values of $C_{p}$ range from 0.3 to 0.93 [Arora 2004] with an average of 0.62 is assumed for this catchment.

The base time was obtained from equation (5)

$$
t_{b}=3+3\left(\frac{t_{l}^{\prime}}{24}\right)
$$

The time width $W_{50}$ and $W_{75}$ of the hydrograph at $50 \%$ and $75 \%$ of the height of the peak flow ordinate were obtained based on equations (6) and (7) respectively in accordance with U.S Army Corps of Engineer [Arora, 2004]. The unit of the time width is hr. Also the peak discharge per area (cumec $/ \mathrm{km}^{2}$ ) is given by equation (8).

$$
\begin{gathered}
W_{50}=\frac{5.9}{\left(q_{p}^{\prime}\right)^{1.08}} \\
W_{75}=\frac{3.4}{\left(q_{p}^{\prime}\right)^{1.08}} \\
q_{p}^{\prime}=\frac{Q_{p}^{\prime}}{A}
\end{gathered}
$$

The output from the equations and the measured physical parameters of each of the basins are presented in Table 1.

\section{Soil Conservation Service (SCS)}

In adopting the method of US Soil Conservation Service (SCS) for constructing synthetic unit hydrographs was based on a dimensionless hydrograph, which relates ratios of time to ratios of flow [Viessman et al. 1989] and Ramirez [2000]. The peak discharge and the time to peak were determined in accordance with [Viessman et al. 1989, Wanielista 1990, Ramirez 2000, SCS 2002, Ogunlela and Kasali 2002, Raghunath 2006] by adopting equations (9) to (12).

\section{Peak discharge}

The peak discharge is obtained through the equation [Ramirez 2000]:

$$
Q_{p}=\frac{0.208 * A^{*} Q_{d} .}{t_{p}}
$$

where: $Q_{p}$ - peak discharge $\left(\mathrm{m}^{3} / \mathrm{s}\right)$

$A$ - watershed area $\left(\mathrm{km}^{2}\right)$

$Q_{d}-$ quantity of run off $(\mathrm{mm})$

$t_{p}$ - time to peak (hr)

Time to peak $\left(t_{p}\right)$ and lag time $\left(t_{l}\right)$ :

$$
\begin{gathered}
t_{p}=\frac{t_{r}}{2}+t_{l} t_{p}=\frac{t_{c}+0.133 t_{c}}{1.7} \\
t_{l}=0.6 t_{c}
\end{gathered}
$$

where: $t_{c}$ - time of concentration (min) 


$$
t_{c}=0.0195\left(\frac{L^{0.77}}{S^{0.385}}\right)
$$

where: $L$ - length of channel (m);

$S$ - slope of channel.

The estimated values of both the peak discharge and time to peak were applied to the dimensionless hydrograph ratios in accordance to SCS and the points for the unit hydrograph were obtained [Raghunath 2006] and used to develop the unit hydrograph curve. The calculated values for parameters $t_{p}$ and $q_{p}$ were applied to the SCS dimensionless unit hydrograph to obtain the corresponding unit hydrograph ordinates. The estimated unit hydrograph ordinates is presented in Table 2 based on the values of time to peak discharge $\left(t_{p}\right)$ and peak discharge $\left(q_{p}\right)$ for each river catchment.

\section{Development of Peak Runoff Hydrographs}

The established unit hydrographs ordinates were used to develop the runoff hydrographs due to actual rainfall event over the catchment. Peak runoff hydrographs for selected return periods (20yr, 50yr, 100yr, 200yr and 500yr) were developed through convolution. The maximum $24-\mathrm{hr}$ rainfall depths of the different recurrence interval for the catchment under consideration are 174.2 $\mathrm{mm}, 205.0 \mathrm{~mm}, 232.3 \mathrm{~mm}, 262.73 \mathrm{~mm}$ and 309.0 $\mathrm{mm}$ respectively [Olofintoye et al. 2009]. The runoff hydrograph was derived from a multiperiod of rainfall excess called hydrograph convolution. It involves multiplying the unit hydrograph ordinates $\left(U_{n}\right)$ by incremental rainfall excess $\left(P_{n}\right)$, adding and lagging in a sequence to produce a resulting runoff hydrograph. The SCS type II curve was used to divide the different rainfall data into successive equal short time events and the SCS Curve Number method was used to estimate the cumulative rainfall for storm depth of $20 \mathrm{yr}, 50 \mathrm{yr}, 100 \mathrm{yr}, 200 \mathrm{yr}$ and $500 \mathrm{yr}$ return period. The incremental rainfall excess was obtained by subtracting sequentially, the rainfall excess from the previous time events. The equations that apply to the SCS Curve Number method are given below [SCS 2002].

Table 1. Watershed characteristics for generating unit hydrograph (Snyder's method)

\begin{tabular}{|l|c|c|c|c|c|c|c|c|}
\hline River watershed & $\mathrm{L}(\mathrm{km})$ & $\mathrm{L}_{\mathrm{c}}(\mathrm{km})$ & $\mathrm{t}_{\mathrm{L}}(\mathrm{hr})$ & $\mathrm{t}_{\mathrm{r}}(\mathrm{hr})$ & $\mathrm{Q}_{\mathrm{p}}\left(\mathrm{m}^{3} / \mathrm{s}\right)$ & $\mathrm{T}_{\mathrm{b}}(\mathrm{hr})$ & $\mathrm{A}\left(\mathrm{km}^{2}\right)$ & $\mathrm{S}(\%)$ \\
\hline Faw-Faw & 11.80 & 6.40 & 5.86 & 1.07 & 13.54 & 89.57 & 46.00 & 0.59 \\
\hline Oba & 23.50 & 10.00 & 8.23 & 1.50 & 78.53 & 96.70 & 375.00 & 0.39 \\
\hline Awun & 35.60 & 20.00 & 11.48 & 2.09 & 60.52 & 106.44 & 403.00 & 0.34 \\
\hline Ogunpa & 22.87 & 13.20 & 8.87 & 1.61 & 21.15 & 98.62 & 108.85 & 0.46 \\
\hline Opeki & 43.50 & 20.00 & 12.19 & 2.22 & 81.31 & 108.57 & 575.00 & 0.21 \\
\hline Otin & 36.00 & 16.00 & 10.77 & 1.96 & 76.01 & 104.31 & 475.00 & 0.36 \\
\hline Osun & 47.50 & 15.00 & 11.48 & 2.09 & 175.66 & 106.44 & 1170.00 & 0.21 \\
\hline Ogun & 600.00 & 315.00 & 61.25 & 11.14 & 574.13 & 255.73 & 20400.00 & 0.07 \\
\hline
\end{tabular}

Table 2. Unit hydrograph ordinates for US Soil Conservation Service (SCS) method

\begin{tabular}{|c|c|c|c|c|c|c|c|c|c|c|c|c|c|c|c|c|c|}
\hline \multicolumn{2}{|c|}{ Faw-Faw River } & \multicolumn{2}{|c|}{ Oba River } & \multicolumn{2}{|c|}{ Awon River } & \multicolumn{2}{c|}{ Ogunpa River } & \multicolumn{2}{c|}{ Opeki River } & \multicolumn{2}{c|}{ Otin River } & \multicolumn{3}{c|}{ Osun River } & \multicolumn{2}{c|}{ Ogun River } \\
\hline $\mathrm{t}(\mathrm{hr})$ & $\mathrm{Q}\left(\mathrm{m}^{3} / \mathrm{s}\right)$ & $\mathrm{t}(\mathrm{hr})$ & $\mathrm{Q}\left(\mathrm{m}^{3} / \mathrm{s}\right)$ & $\mathrm{t}(\mathrm{hr})$ & $\mathrm{Q}\left(\mathrm{m}^{3} / \mathrm{s}\right)$ & $\mathrm{t}(\mathrm{hr})$ & $\mathrm{Q}\left(\mathrm{m}^{3} / \mathrm{s}\right)$ & $\mathrm{t}(\mathrm{hr})$ & $\mathrm{Q}\left(\mathrm{m}^{3} / \mathrm{s}\right)$ & $\mathrm{t}(\mathrm{hr})$ & $\mathrm{Q}\left(\mathrm{m}^{3} / \mathrm{s}\right)$ & $\mathrm{t}(\mathrm{hr})$ & $\mathrm{Q}\left(\mathrm{m}^{3} / \mathrm{s}\right)$ & $\mathrm{t}(\mathrm{hr})$ & $\mathrm{Q}\left(\mathrm{m}^{3} / \mathrm{s}\right)$ \\
\hline 0.0 & 0.0 & 0.0 & 0.0 & 0.0 & 0.0 & 0.0 & 0.0 & 0.0 & 0.0 & 0.0 & 0.0 & 0.0 & 0.0 & 0.0 & 0.0 \\
\hline 1.1 & 19.7 & 2.1 & 80.2 & 3.0 & 59.6 & 1.9 & 25.3 & 4.3 & 60.4 & 3.0 & 70.7 & 4.6 & 114.8 & 50.2 & 181.9 \\
\hline 2.1 & 45.8 & 4.2 & 186.5 & 6.1 & 138.7 & 3.9 & 58.9 & 8.5 & 140.4 & 6.0 & 164.1 & 9.1 & 267.0 & 100.4 & 422.9 \\
\hline 3.2 & 30.2 & 6.3 & 123.1 & 9.1 & 91.6 & 5.8 & 38.9 & 12.8 & 92.7 & 9.0 & 108.5 & 13.7 & 176.2 & 150.5 & 279.1 \\
\hline 4.2 & 14.7 & 8.4 & 59.7 & 12.1 & 44.4 & 7.7 & 18.9 & 17.1 & 44.9 & 12.0 & 52.6 & 18.2 & 85.4 & 200.7 & 135.3 \\
\hline 5.2 & 7.1 & 10.5 & 28.9 & 15.1 & 21.5 & 9.6 & 9.2 & 21.3 & 21.8 & 15.0 & 25.5 & 22.8 & 41.4 & 250.9 & 65.6 \\
\hline 6.3 & 3.4 & 12.6 & 14.0 & 18.1 & 10.4 & 11.6 & 4.4 & 25.6 & 10.5 & 18.0 & 12.3 & 27.4 & 20.0 & 301.0 & 31.7 \\
\hline 7.3 & 1.7 & 14.7 & 6.7 & 21.2 & 5.0 & 13.5 & 2.1 & 29.8 & 5.1 & 21.0 & 5.9 & 31.9 & 9.6 & 351.2 & 15.2 \\
\hline 8.4 & 0.8 & 16.7 & 3.4 & 24.2 & 2.5 & 15.4 & 1.1 & 34.1 & 2.5 & 24.1 & 3.0 & 36.5 & 4.8 & 401.4 & 7.6 \\
\hline 9.4 & 0.4 & 18.8 & 1.7 & 27.2 & 1.3 & 17.3 & 0.6 & 38.4 & 1.3 & 27.1 & 1.5 & 41.0 & 2.4 & 451.5 & 3.8 \\
\hline 10.5 & 0.2 & 20.9 & 0.8 & 30.2 & 0.6 & 19.2 & 0.3 & 42.6 & 0.6 & 30.1 & 0.7 & 45.6 & 1.1 & 501.7 & 1.7 \\
\hline 11.5 & 0.0 & 23.0 & 0.0 & 33.3 & 0.0 & 21.2 & 0.0 & 46.9 & 0.0 & 33.1 & 0.0 & 50.2 & 0.0 & 551.9 & 0.0 \\
\hline
\end{tabular}




$$
\begin{aligned}
Q_{d} & =\frac{\left(P^{*}-I_{a}\right)^{2}}{P^{*}+0.8 S} \text { for } P^{*}>0.2 S \\
Q_{d} & =0 \text { for } P^{*} \leq 0.2 S
\end{aligned}
$$

where: $P^{*}$-accumulated precipitation $(\mathrm{mm})$

$Q_{d}$ - cumulative rainfall excess, runoff $(\mathrm{mm})$

$I_{a}$ - initial abstraction, $I_{a}=0.2 \mathrm{~S}$.

$$
S=\frac{25400}{C N}-254
$$

With the $C N=75$ based on soil group B, small grain and good condition, $S$ is estimated as $84.67 \mathrm{~mm}$, while $I_{a}$ is $16.94 \mathrm{~mm}$. This implies that any value of rainfall less than $16.94 \mathrm{~mm}$ is regarded as Zero.

The runoff hydrograph peak flows obtained for the catchments of Fawfaw, Oba, Awon, Ogunpa, Opeki, Otin, Osun and Ogun Rivers based on the two methods of synthetic unit hydrographs and various return periods are presented in Table 3.

\section{RESULTS AND DISCUSSIONS}

Two methods of synthetic unit hydrograph were adopted to determine the ordinates for the development of peak runoff hydrograph for eight catchments listed. The values of the ordinate from the synthetic unit hydrograph methods were presented in Tables 1 and 2 while the runoff hydrograph peak flows $\left(\mathrm{m}^{3} / \mathrm{s}\right)$ for the eight river catchments are presented in Table 3.

It was observed for Faw-Faw river catchment that the values obtained for SCS method is higher by $63.31 \%$ than that of Snyder method. For Oba river catchment, the values obtained for SCS method is higher by $45.88 \%$ than that of Snyder. Also for Awon river catchment, the values obtained for SCS method is higher by $40.66 \%$ than that of Snyder. Likewise, for Ogunpa river catchment, the value obtained for SCS method is higher by $54.46 \%$ than that of Snyder method. For Opeki river catchment, the values obtained for SCS method is higher by $23.20 \%$

\begin{tabular}{|c|c|c|c|c|c|}
\hline \multirow{2}{*}{ Methods } & \multicolumn{5}{|c|}{ Storm return periods } \\
\hline & $20 \mathrm{yr}, 24 \mathrm{hr}$ & $50 \mathrm{yr}, 24 \mathrm{hr}$ & $100 \mathrm{yr}, 24 \mathrm{hr}$ & $200 \mathrm{yr}, 24 \mathrm{hr}$ & $500 \mathrm{yr}, 24 \mathrm{hr}$ \\
\hline \multicolumn{6}{|c|}{ Faw-Faw River catchment } \\
\hline Snyder & 112.63 & 143.70 & 171.28 & 203.15 & 352.34 \\
\hline SCS & 304.43 & 388.06 & 464.59 & 556.52 & 699.89 \\
\hline \multicolumn{6}{|c|}{ Oba River catchment } \\
\hline Snyder & 678.80 & 866.23 & 1030.03 & 1218.99 & 1510.35 \\
\hline SCS & 1240.54 & 1581.35 & 1893.19 & 2267.81 & 2852.03 \\
\hline \multicolumn{6}{|c|}{ Awon River catchment } \\
\hline Snyder & 555.52 & 707.11 & 839.52 & 992.08 & 1227.17 \\
\hline SCS & 922.46 & 1175.88 & 1407.77 & 1686.34 & 2120.76 \\
\hline \multicolumn{6}{|c|}{ Ogunpa River catchment } \\
\hline Snyder & 180.44 & 230.26 & 273.80 & 324.02 & 401.46 \\
\hline SCS & 391.89 & 499.55 & 598.06 & 716.40 & 900.96 \\
\hline \multicolumn{6}{|c|}{ Opeki River catchment } \\
\hline Snyder & 724.84 & 925.16 & 1100.29 & 1302.34 & 1613.93 \\
\hline SCS & 933.81 & 1190.34 & 1425.08 & 1707.08 & 2146.84 \\
\hline \multicolumn{6}{|c|}{ Otin River catchment } \\
\hline Snyder & 672.80 & 858.83 & 1021.46 & 1209.10 & 1498.46 \\
\hline SCS & 1093.50 & 1393.91 & 1668.80 & 1999.02 & 2513.93 \\
\hline \multicolumn{6}{|c|}{ Osun River catchment } \\
\hline Snyder & 1558.63 & 1989.43 & 2366.10 & 2800.66 & 3470.81 \\
\hline SCS & 1775.65 & 2263.46 & 2709.82 & 3246.04 & 4082.25 \\
\hline \multicolumn{6}{|c|}{ Ogun River catchment } \\
\hline Snyder & 6018.71 & 7672.82 & 9120.66 & 10790.02 & 13364.33 \\
\hline SCS & 2812.87 & 3585.63 & 4292.72 & 5142.16 & 6466.84 \\
\hline
\end{tabular}
than that of Snyder. For Otin river catchment,

Table 3. Peak runoff hydrograph $\left(\mathrm{m}^{3} / \mathrm{s}\right)$ 
a)

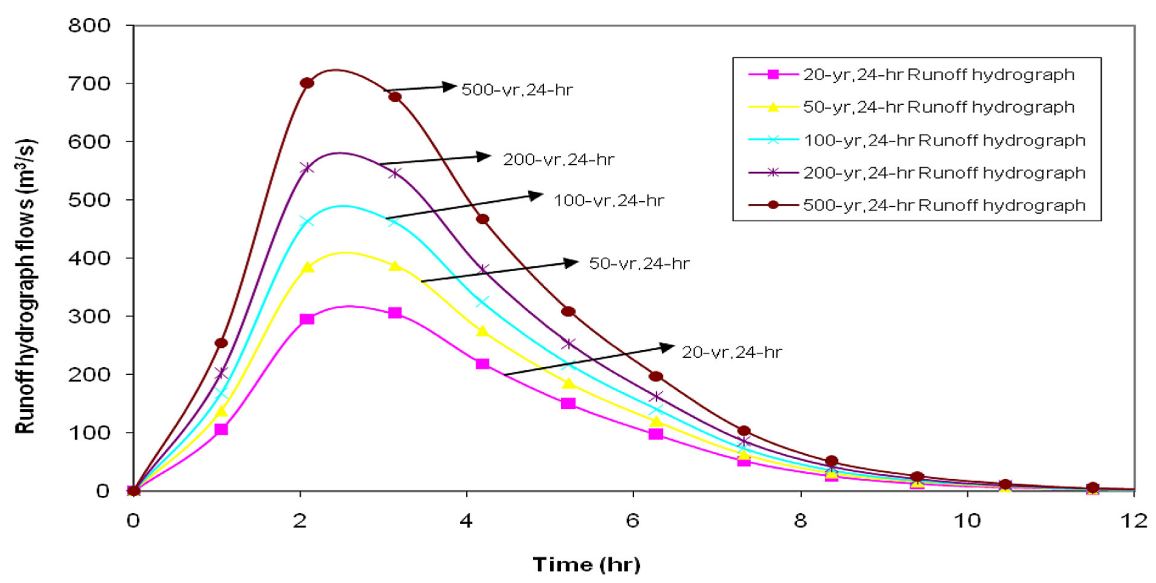

b)

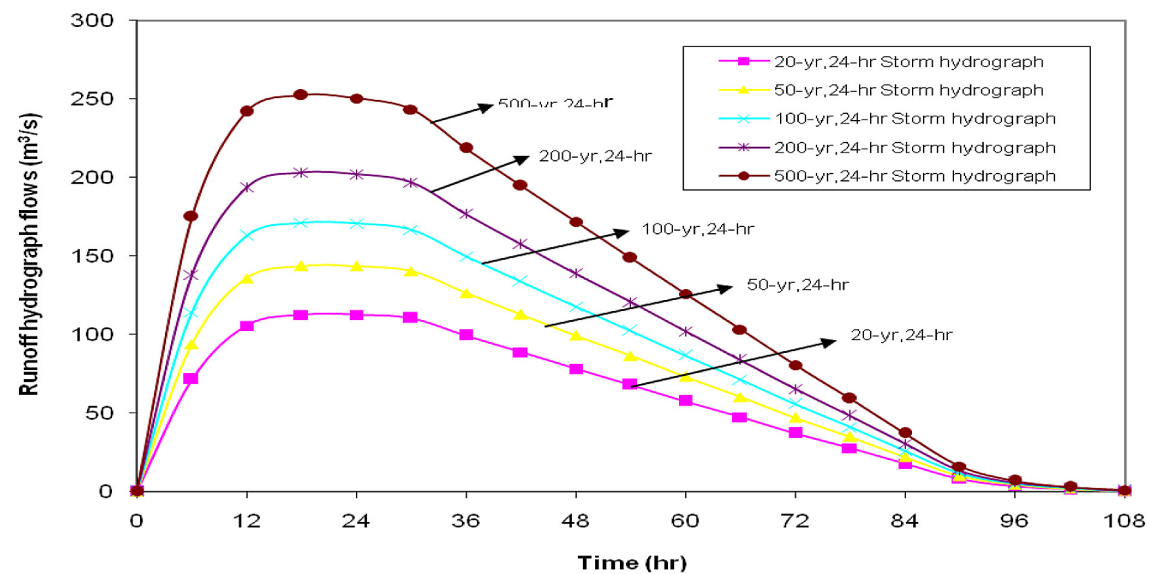

Figure 2. Runoff hydrograph of different return periods for Faw-faw River: a) SCS method, b) Snyder method

a)

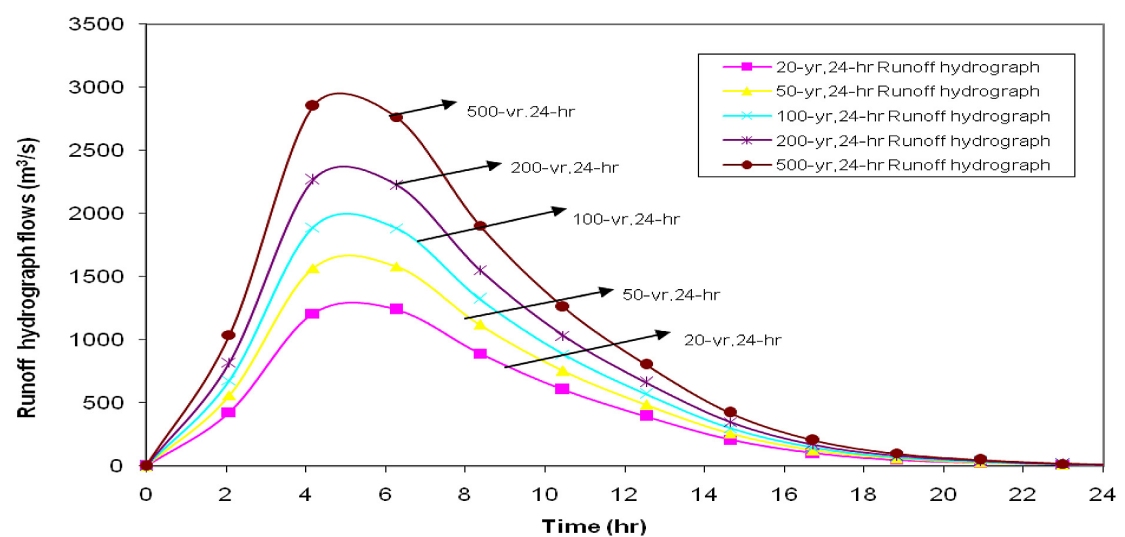

b)

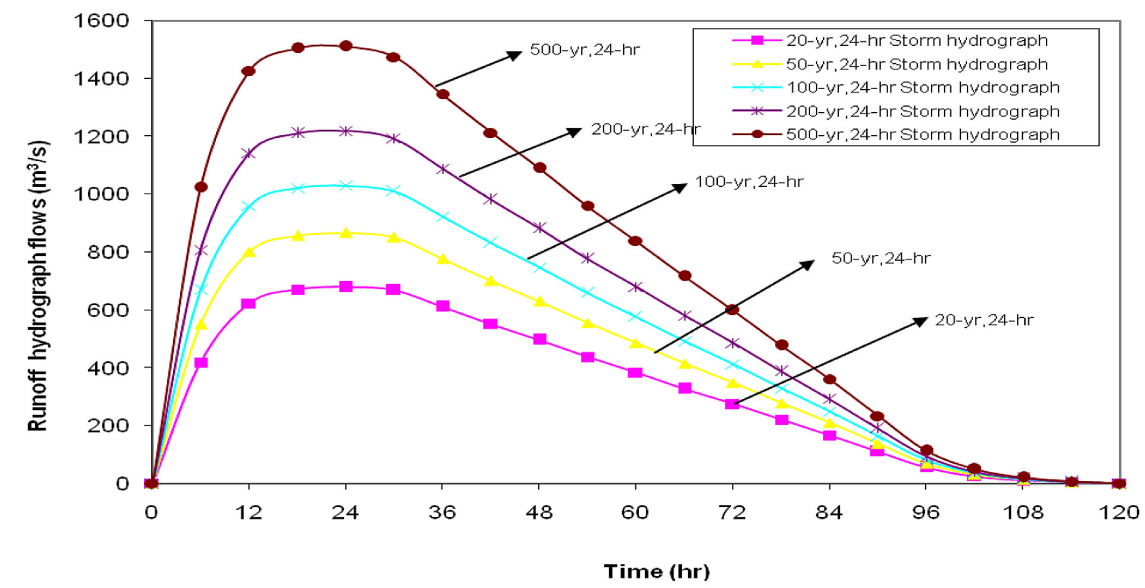

Figure 3. Runoff hydrograph of different return periods for Oba River: a) SCS method, b) Snyder method 
a)

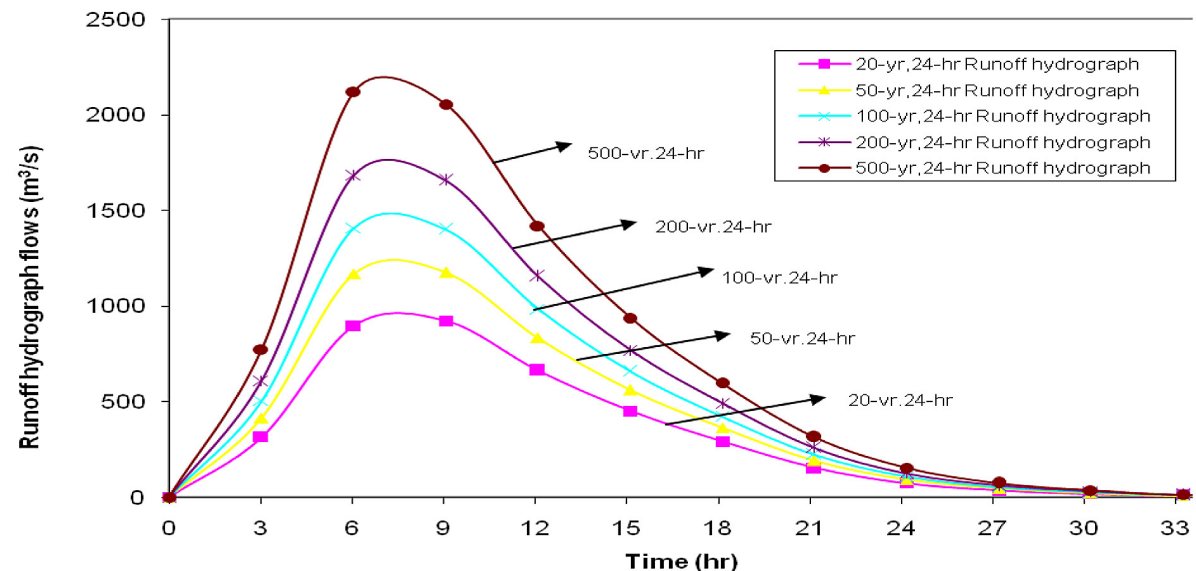

b)

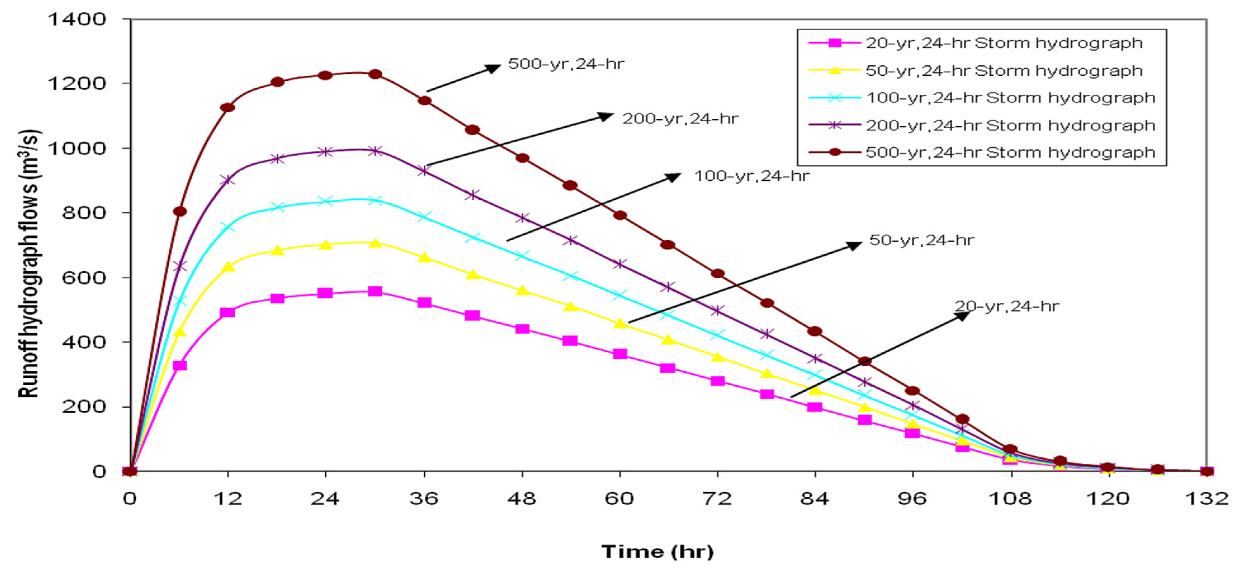

Figure 4. Runoff hydrograph of different return periods for Awon River: a) SCS method, b) Snyder method

a)

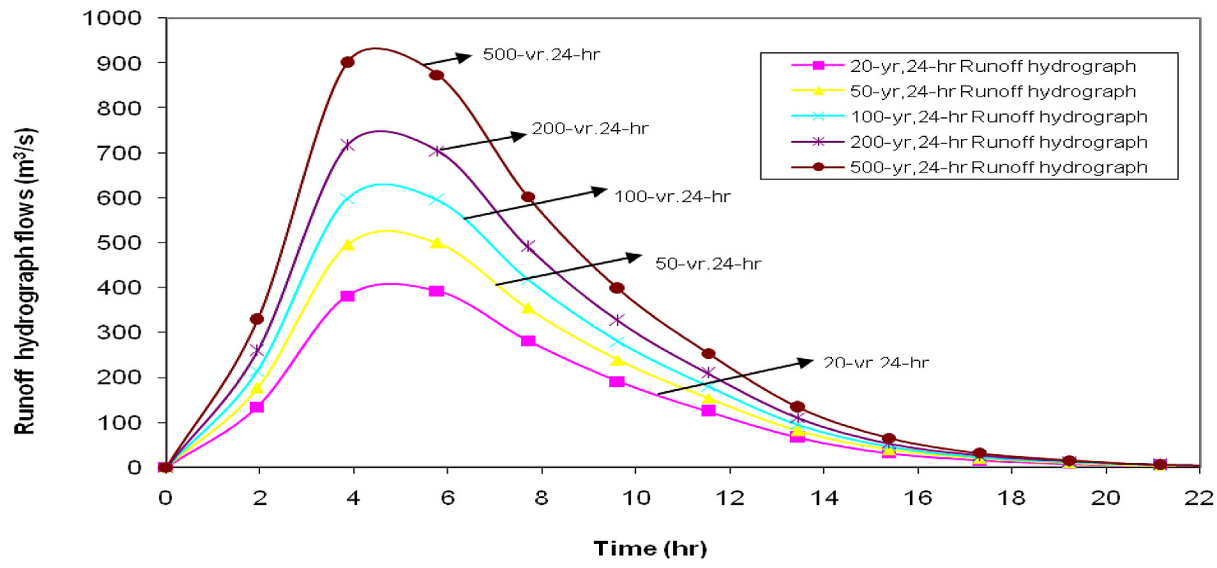

b)

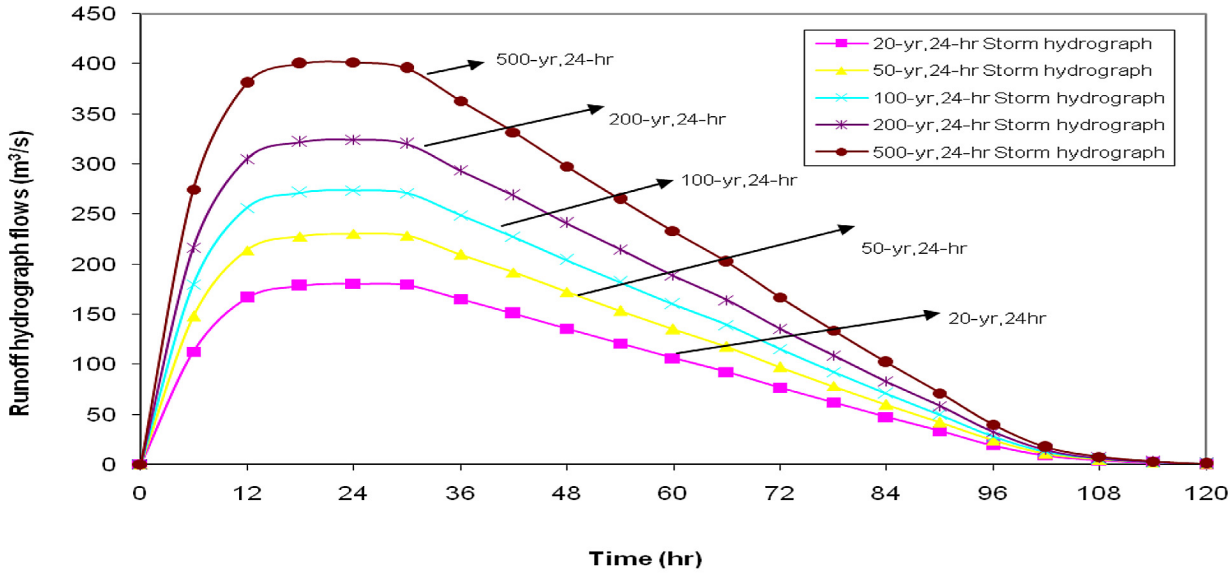

Figure 5. Runoff hydrograph of different return periods for Ogunpa River: a) SCS method, b) Snyder method 
a)

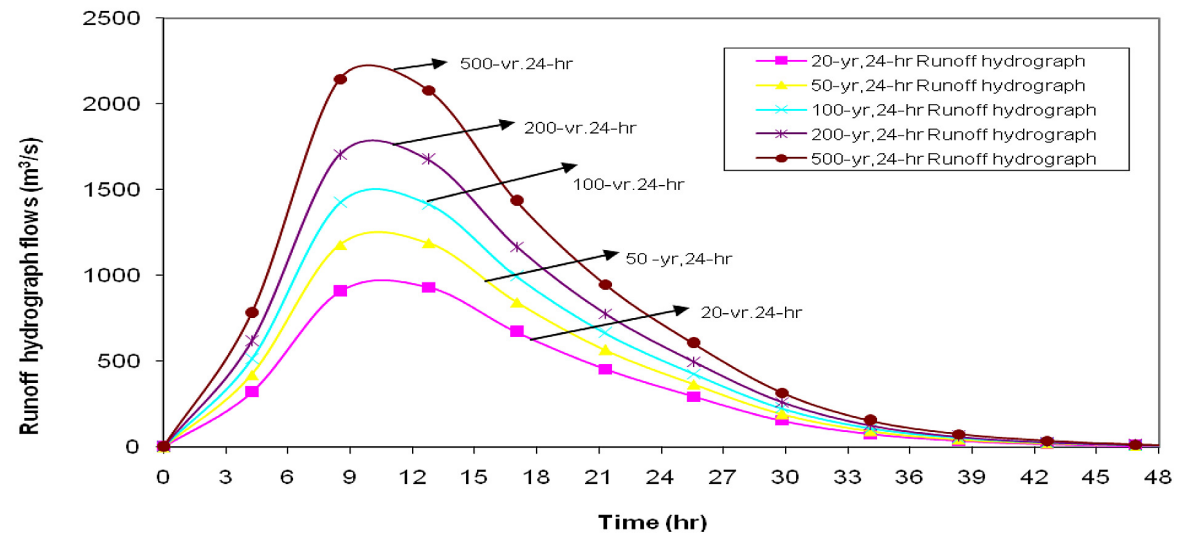

b)

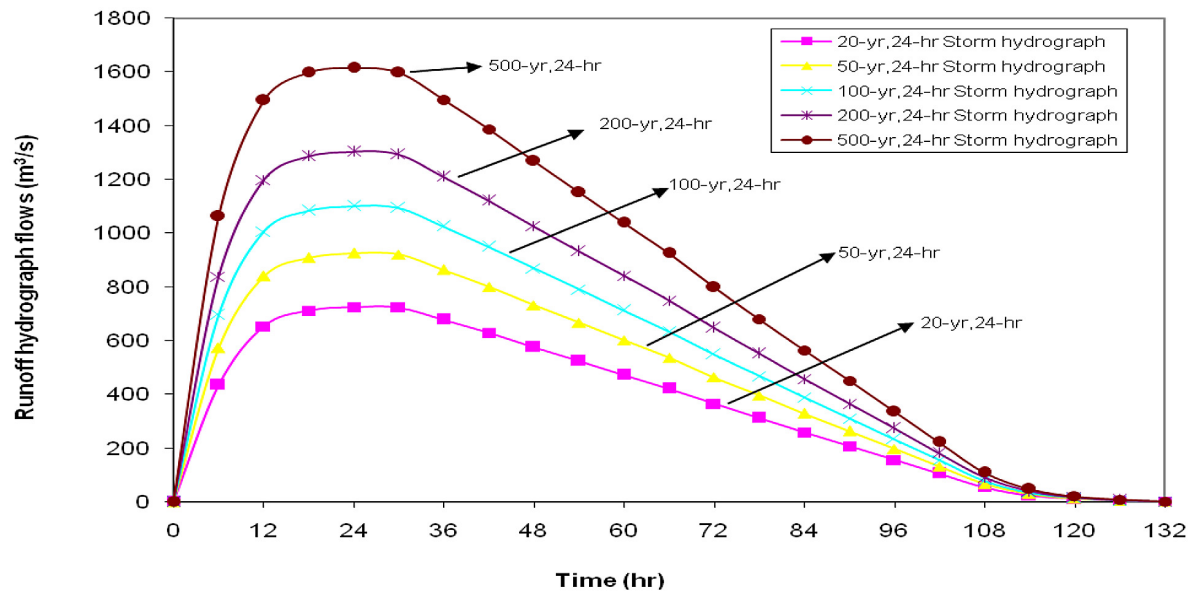

Figure 6. Runoff hydrograph of different return periods for Opeki River: a) SCS method, b) Snyder method

a)

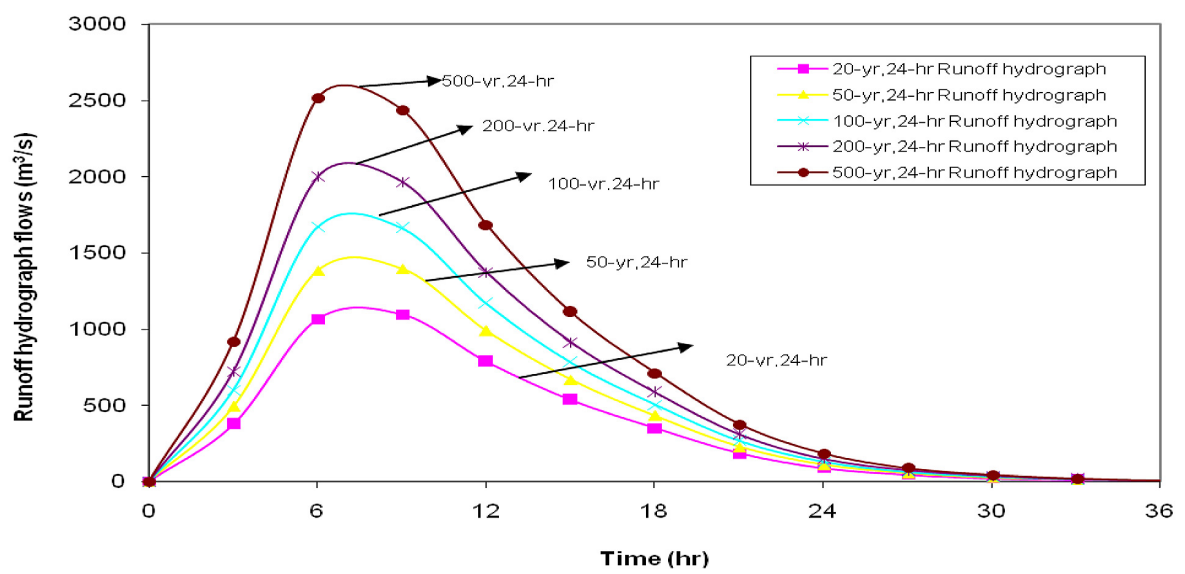

b)

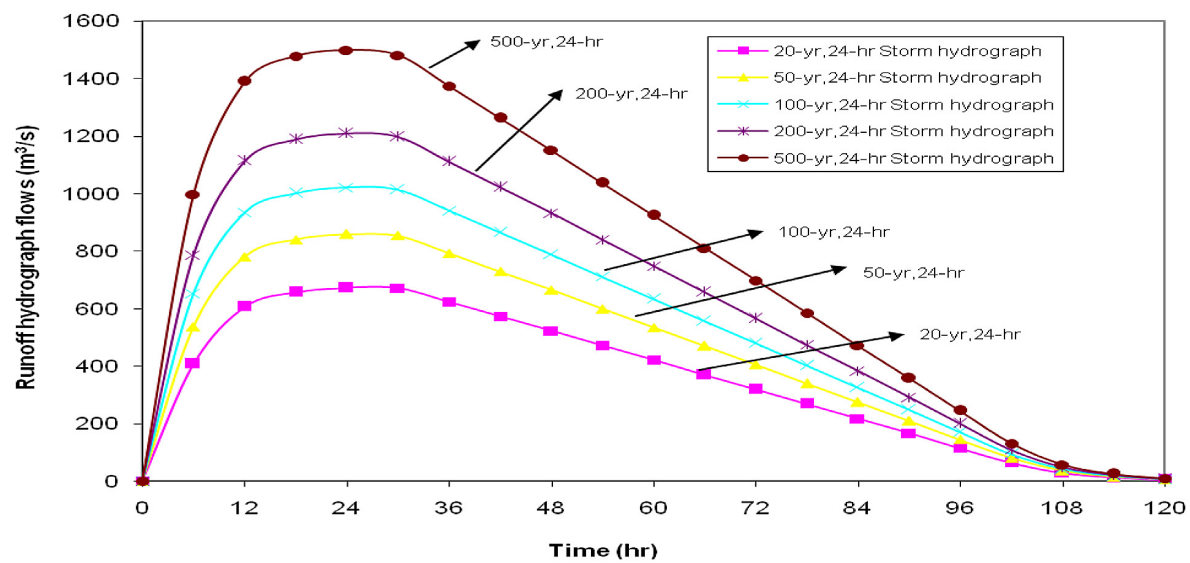

Figure 7. Runoff hydrograph of different return periods for Otin River: a) SCS method, b) Snyder method 
a)

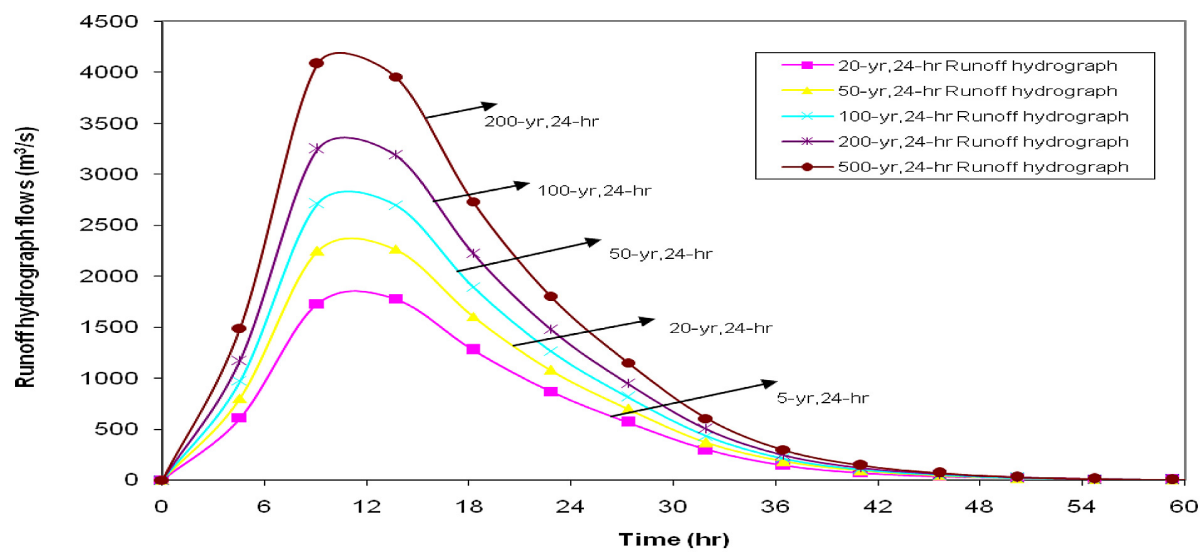

b)

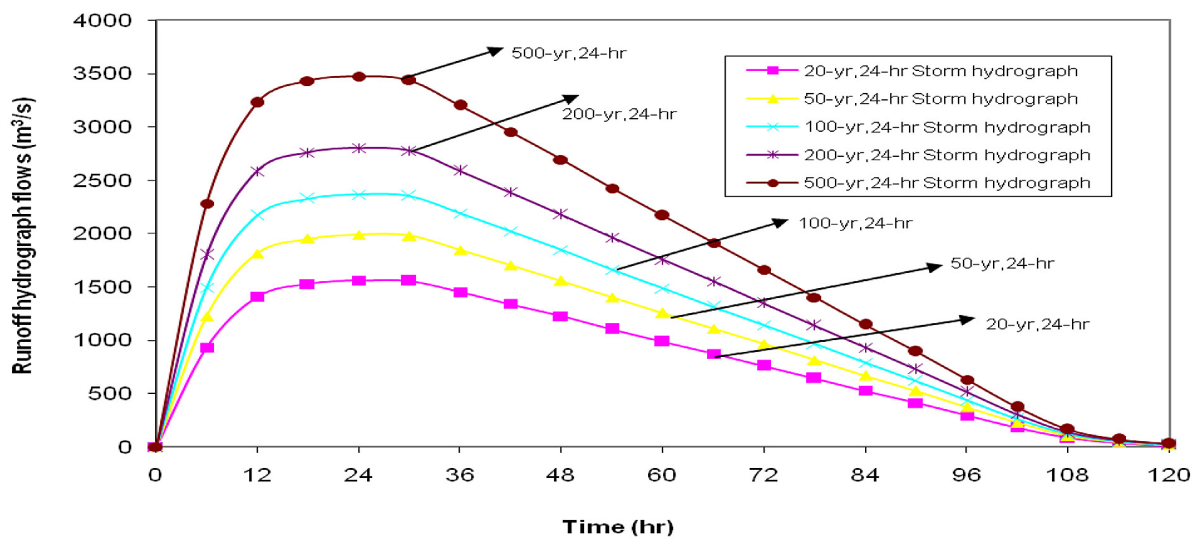

Figure 8. Runoff hydrograph of different return periods for Osun River: a) SCS method, b) Snyder method

a)

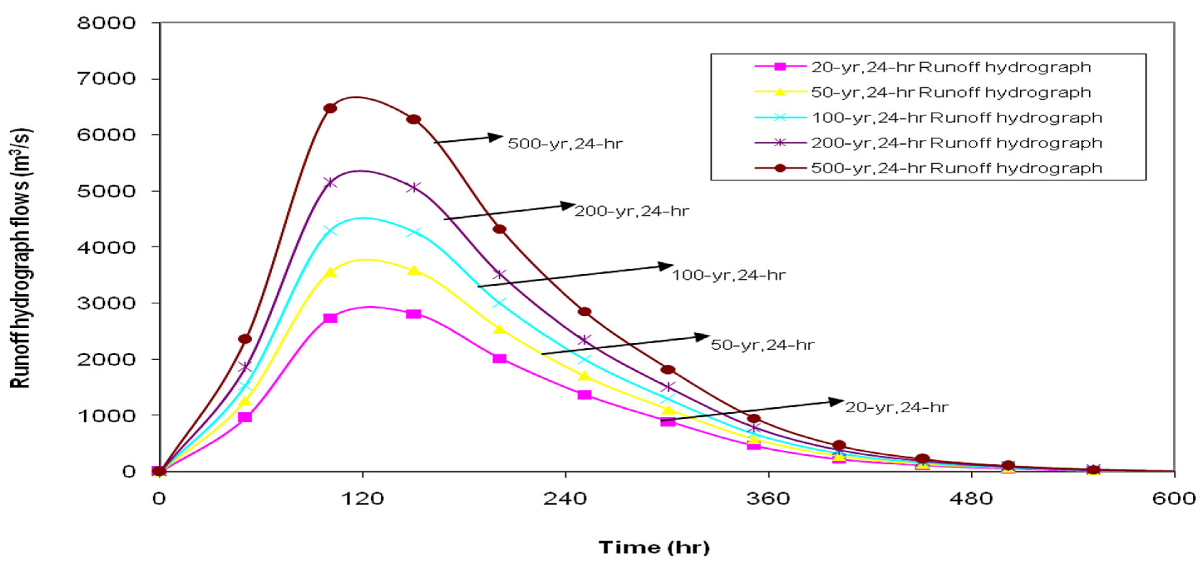

b)

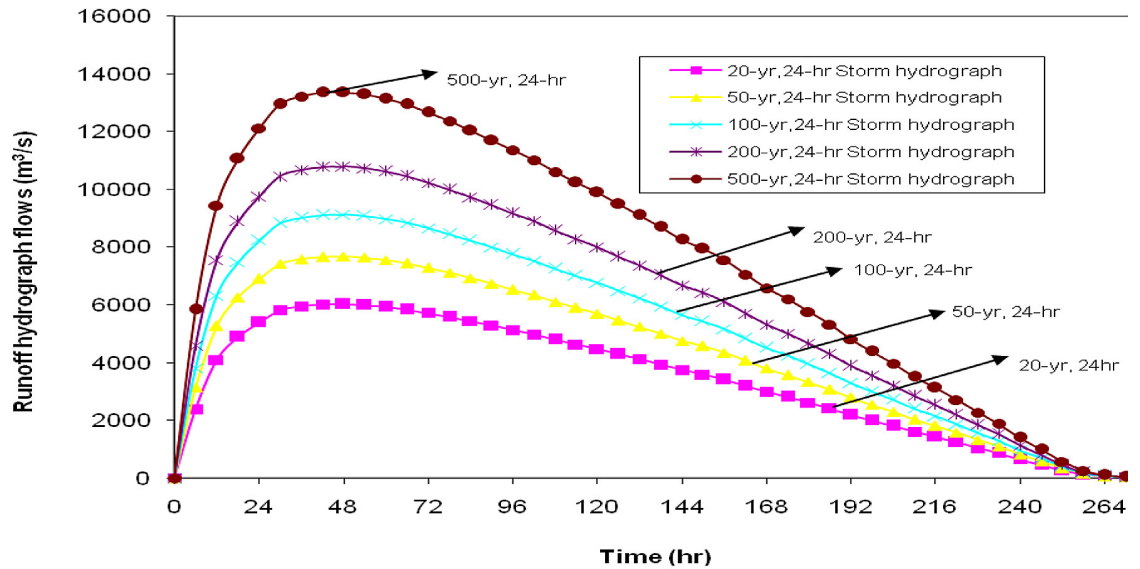

Figure 9. Runoff hydrograph of different return periods for Ogun River: a) SCS method, b) Snyder method 
the values obtained for SCS method is higher by $39.11 \%$ than that of Snyder. For Osun river catchment, the values obtained for SCS method is higher by $13.14 \%$ than that of Snyder method. For Ogun river catchment, the values obtained for Snyder method is higher by $52.06 \%$ than that of SCS method. This implies that, the percentage difference shows that for values of peak flows obtained by Snyder and SCS methods varies from $13.14 \%$ to $63.30 \%$.

The runoff hydrograph for the river catchment based on the unit hydrograph obtained with SCS method are presented in Figures 2a to 9a, while those obtained with Snyder method are presented in Figures $2 b$ to $9 b$ for adoption at the study area.

\section{CONCLUSION}

The percentage difference for values of peak flows obtained with Snyder and SCS methods varies from $13.14 \%$ to $63.30 \%$. However, SCS method is recommended because it utilized additional morphometric parameters such as watershed slope and the curve number $(\mathrm{CN})$ which is a function of the properties of the soil and vegetation cover of the watershed in the estimation of ordinate required for the development of peak runoff hydrograph in the river watersheds.

\section{REFERENCES}

1. Arora K.R. 2004. Irrigation, water power and water Resources Engineering. Standard Publishers Distributions, 1705-B, NAI SARAK, Delhi, 79-106.

2. Chow V.T., Maidment D.R. and Mays L.W. 1988. Applied Hydrology: McGraw - Hill Publishing company, New York.

3. Jones B.S. 2006. Five - minute unit hydrographs for selected Texas Watersheds. M.Sc Thesis in Civil Engineering submitted to the Graduate Faculty of Texas Tech. University.
4. Murray R.S and Larry J.S. 2000. Theory and Problems of Statistics. Third edition. Tata, McGrawHill Publishing Company Limited, New Delhi.

5. Ogunlela A.O and Kasali. M.Y. 2002. Evaluation of four methods of storm hydrograph development for an ungaged watershed. Published in Nigerian Journal of Technological development. Faculty of engineering and Technology, University of Ilorin, Ilorin, Nigeria (2), 25-34.

6. Olofintoye O.O, Sule B.F and Salami A.W. 2009. Best-fit Probability Distribution model for peak daily rainfall of selected Cities in Nigeria. New York Science Journal, 2(3).

7. Ramirez J.A. 2000. Prediction and Modeling of Flood Hydrology and Hydraulics. Chapter 11 of Inland Flood Hazards: Human, Riparian and Aquatic Communities. Edited by Ellen Wohl; Cambridge University Press.

8. Raghunath H.M. 2006. Hydrology: Principles, Analysis and Design. New Age International (P) Limited, Publishers, New Delhi. $2^{\text {nd }}$ edition.

9. Salami A.W. 2009. Evaluation of Methods of Storm Hydrograph Development. International Egyptian Engineering Mathematical Society IEEMS, Zagazig University Publications. International e-Journal of Egyptian Engineering Mathematics: Theory and Application (6), 17-28 (http://www.ieems.net/ iejemta.htm).

10. SCS 2002. Soil Conservation Service. Design of Hydrograph. US Department of agriculture, Washington, DC.

11. Varshney R.S. 1986 Engineering Hydrology. NEM Chand \& Bros, Roorkee (U.P), India.

12. Viessman W., Knapp J.W. and Lewis G.L. 1989. Introduction to Hydrology, Harper and Row Publishers, New York, 149-355.

13. Wanielista M.P. 1990. Hydrology and Water Quantity Control. John Willey and Sons. Inc.

14. Warren V., Terence E.H. and John W.K. 1972. Introduction to hydrology. Intext Educational Publishers, $2^{\text {nd }}$ edition, New York, 106-141.

15. Wilson E.M. 1990. Engineering Hydrology. Macmillan Press Ltd. $2^{\text {nd }}$ edition Houndmills, Basingstoke, Hampshire and London, 172-180. 